\title{
O egzystencji w dziele literackim i o egzystencji dzieła*
}

\begin{abstract}
Wachowski Jacek, O egzystencji $w$ dziele literackim i o egzystencji dzieła [On the existence of literary work and on existence in literary work]. „Przestrzenie Teorii” 28. Poznań 2017, Adam Mickiewicz University Press, pp. 79-94. ISSN 1644-6763. DOI 10.14746/pt.2017.28.2.

The concept of existence is rooted in (at least) two traditions: philosophical and literary theory. This does not mean, however, that it means the same for both fields. The first tradition is wide ranging because it includes diverse - physical, emotional and spiritual (as well as intellectual) aspects of being. The second tradition is narrow and it closely refers to literary output. Literary existence - which is based on physical reality - is permanently separated from it. Literature refers to the representation and imagination of the world, not to the empirical experience of physical reality. In addition, literature does not apply the categories of truth and falsehood that we know from social reality (because literary existence stands, beyond the assertion). It is also imprisoned in genology - inscribed in the genre. Literary existence has more to do with poetry, style, artistic convention than what philosophers are examining. Sometimes great literary works deal with great philosophical problems, but sometimes do not and it do not detract from their artistic nature. Both of these tradition - literary and philosophical - however, have many common places, require careful study and analysis. The article is an attempt to show these places and characterize their features.
\end{abstract}

KEYWORDS: existence, being, literary theory, philosophy

W X księdze Polithei ${ }^{1}$ mówi Platon, że „poeci kłamią”. Słowa te - podobnie jak uwagi pochodzące z wczesnego Iona (gdzie ustami Sokratesa wypowiada pogląd, iż poeci sa,,istotami skrzydlatymi” - jak owady nawiedzone przez muzy albo przez bogów i że brzęczą coś, ale ma to niewiele wspólnego z logosem $)^{2}-$

* Artykuł jest skróconą wersją wykładu wygłoszonego na konferencji: „O egzystencji. Między filozofią a literatura”, zorganizowanej przez Instytut Filozofii UAM oraz Polskie Towarzystwo Antropologii Filozoficznej (9 czerwca 2017 roku w Poznaniu).

${ }^{1}$ Platon, Państwo, 597-598, [w:] tegoż, Państwo, Prawa, tłum. W. Witwicki, Kęty 1999, s. 310-313. W projekcie idealnego państwa zarzuca Platon poetom oddalenie od alethei (która dość nieprecyzyjnie tłumaczy się jako prawdę); $\grave{\alpha}-\lambda \eta \dot{\eta} \theta \varepsilon ı \alpha$ literalnie oznaczało stan „nie bycia ukrytym”, odnosiło się więc do: „ujawnienia”, „odkrycia”, a zatem do faktyczności i realności. $\mathrm{W}$ tym także do prawdy, jeśli prawda zawierała się w owych stanach.

${ }^{2}$ Zob. tenże, Ion, 534 B-C, [w:] tegoż, Dialogi, t. 1, tłum. W. Witwicki, Kęty 1999, s. $21-22$. 
określiły na wiele stuleci stosunek filozofów do poetów ${ }^{3}$. Nawet jeśli spór między nimi ${ }^{4}$ próbowali załagodzić: najpierw Arystoteles i Cyceron, a później Petrarka (który na zarzuty Platona odpowiadał, że pragnienie dobra to coś więcej niż poznanie prawdy), to słowa z Polithei wyznaczyły relacje między poetami i filozofami na szereg kolejnych stuleci 5 .

Przeświadczenie o niezależności obu dyskursów (i właściwych dla nich sposobów poznawania) wynikało również z tego, że pytania filozoficzne nie stanowia koniecznego wyposażenia dzieł literackich - podobnie jak rozważania filozoficzne nie odnoszą się zawsze (można nawet powiedzieć, że odnoszą się rzadko) do literatury. Jeśli powstaje wrażenie, że (wszystkie!) dzieła literackie dotykają ważnych kwestii filozoficznych - a może nawet, że są ich artystycznymi parafrazami - to źródłem takich przypuszczeń jest najczęściej trud literaturoznawców, którzy dzięki swoim interpretacjom (czasem nadinterpretacjom) potrafią przekonać czytelników do ukrytej obecności wielkich dylematów filozoficznych w utworach literackich.

Niewykluczone, że literaturoznawcy - obsadzając się w roli negocjatorów - nabrali przekonania, iż mogą zakończyć spór między poetami i filozofami, a może nawet doprowadzić do trwałego pojednania zwaśnionych stron. $\mathrm{W}$ istocie jednak - w swoim sposobie dociekania - sa oni (literaturoznawcy) podobni do poetów. Mówiąc o filozofii, mają (najczęściej) na myśli coś innego niż filozofowie. Ich przekonanie, że filozofuja, nie oznacza bowiem, iż wypowiadają myśli filozoficzne w znaczeniu właściwym dla filozofii. Raczej, że przenoszą wybrane dylematy poznawcze na grunt swojej dyscypliny i wykorzystują je do charakterystyki literackich dzieł. Filozofia staje się dla nich dyscyplina pomocnicza, kontekstem, appendiksem interpretacyjnym, podporządkowanym celom estetycznym.

$\mathrm{Z}$ drugiej jednak strony nie można powiedzieć, iż między literaturoznawstwem i filozofią nie występuja powinowactwa, że nie ma punktów wspólnych i linii przecięcia. Przeciwnie, jest ich całkiem sporo. Te najważniejsze dotyczą zagadnień związanych z egzystencją i odnoszą się do kilku zasadniczych kwestii (które stały się ważną inspiracją współczesnego literaturoznawstwa). Zawierają się one w pytaniach: w jaki sposób istnieje świat przedstawiony w dziele literackim? W jaki sposób istnieja postaci,

${ }^{3}$ Zob. K. Bartol, Wypędzić poezję, wygnać poetów. Wspótczesne interpretacje Platońskiego postulatu, „Poznańskie Studia Polonistyczne” Seria Literacka, 2012, nr 19, s. 13-30.

${ }^{4}$ Komentatorzy Polithei zwracają przy tym uwagę, że w tekście znajdujemy dwie wykluczające się uwagi. W księdze III postuluje Platon objęcie poezji cenzurą, a w X mówi już o całkowitym wypędzeniu poetów z państwa. Zob. J. Annas, An Introduction to Plato's Republic, Oxford 1981, s. 342, cyt. za K. Bartol, dz. cyt., s. 15.

${ }^{5}$ Zob. A. Gawroński, Dlaczego Platon wykluczyt poetów z państwa? U źródet wspótczesnych badań nad językiem, przedmowa Z. Kubiak, Warszawa 1984, s. 39-64. 
a także byty nieludzkie? Od czego zależy ich egzystencja i co na nią wpływa? Wreszcie, jak istnieje samo dzieło literackie? Co to znaczy, że istnieje i w jaki sposób to istnienie ujawnia się odbiorcom?

Pytania te wyznaczają nie tylko główne kierunki badań literaturoznawczych, ale uświadamiają też, że badacze literatury, mówiąc o istnieniu - a więc przenosząc na grunt swojej dyscypliny jeden z najważniejszych dylematów filozoficznych - posługują się trzema zawężeniami. Wynikają one z charakteru badań literaturoznawczych i dotycza: 1) zakresu pojęcia egzystencji i tego, co potrafimy nim objaćc; 2) gatunków literackich, czyli środowiska, w którym występuje to, co nazywamy egzystencja; 3) sposobu, w jaki istnieje (egzystuje) dzieło literackie $\mathrm{i}$ - co może ważniejsze - w jaki ujawnia się czytelnikom.

\section{2.}

Pierwsze uściślenie - dotyczące denotacji - świadczy o tym, że badacze literatury rozumieją egzystencję dość przewrotnie: klasycznie i nieklasycznie zarazem. Z jednej strony pojmują ją jako ekspresję bytu w znaczeniu, które wiąże się z istnieniem i łączy się ze sposobem bytowania - a więc jako esse, które jest wewnętrznym pryncypium, aktualizującym istotę tego, co bytuje (czyli essentia) i czyni byt realnym, to znaczy faktycznym ${ }^{6}$. Z drugiej jednak strony, odnosza ja (egzystencję) do bytowania przedstawicieli nie tylko swojego gatunku. W odróżnieniu od ujęć klasycznych, samą esse rozumieją więc jako składnik bytu przysługujący wszystkim istnieniom, także nieludzkim. Zdarza się też, że pojmują ją na sposób Heideggerowski, jako akt bycia, który poprzedza wszelkie formy namysłu nad nim, czynione zarówno przez sam byt/podmiot (jeśli jest do tego zdolny), jak też przez tych wszystkich, którzy pragnęliby jakąkolwiek refleksję na jego temat wypowiedzieć.

Perspektywę taka wymuszaja w pewnym sensie same dzieła literackie, które prowokuja do odejścia od antropocentrycznej tradycji patrzenia na świat (w tym także uprawiania filozofii). Oto bowiem w przestrzeni dzieł literackich bytami nie mniej ważnymi niż ludzie - a niejednokrotnie obdarzonymi większą moca sprawcza - okazuja się zwierzęta (różnego gatunku), a także przedmioty nieożywione. Warto przy tym dodać, że personifikacja - która jest chwytem tak starym jak literatura - uczłowiecza zwierzęta i materię nieożywioną według tego samego schematu - wyposaża byty nieludzkie w potencjał komunikacyjny (mowę i ruch) oraz amplifikuje

${ }^{6}$ Por. m.in. A. Wawrzyniak, Egzystencja, [w:] Powszechna encyklopedia filozofii, red. A. Maryniarczyk, t. 3. Lublin 2002, s. 33-34. 
ich (często nadprzyrodzone) możliwości ${ }^{7}$. Praktyka ta łączy się z oddaniem im części przywilejów należących do człowieka - z ustapieniem im miejsca (liczne przykłady takich zabiegów znajdujemy w prozie Brunona Schulza, poezji Mirona Białoszewskiego i Bolesław Leśmiana, podobnie jak w literaturze baśniowej i fantastycznej).

$\mathrm{Z}$ drugiej jednak strony, nadawanie cech ludzkich skałom, rzekom, lasom - a także sprzętom tak pospolitym jak krzesła, stoły i szafy z ich zawartościami - można uznać za formę kryptoprzemocy i próbę podporządkowania ich natury światu opartemu na ludzkich algorytmach komunikacyjno-aksjologicznych. W takim ujęciu drzewa, które mówią a nawet poruszają się, i szuflady, które rozmawiaja z krzesłami, staja się symbolami intelektualnej kolonizacji - podboju egzystencji słabszych przez przedstawicieli silniejszego gatunku.

Praktyki stosowane w tym względzie przez literaturoznawców nie wydają się jednak chaotyczne. Przeciwnie, przebiegają wedle ustalonych i dobrze znanych reguł. O ich statusie decyduje oddalenie od ludzkiego świata ${ }^{8}$. Jeśli zatem za egzystencje pierwszego stopnia uznamy wszystkie postaci ludzkie, występujące w dziełach literackich, to w drugim szeregu znajdą się byty nieludzkie: zwierzęta i rośliny. Poziom trzeci tworzyć będzie materia nieożywiona - przedmioty i obiekty obdarzone przez autorów wolą istnienia. Czwarty poziom to złożenia i transformacje materii ożywionej i nieożywionej. W ten sposób powstają byty chimeryczne, często nieciagłe, naznaczone nowymi sensoryczno-poznawczymi atrybutami. Dotyczyć to może zarówno dowolnych transformacji ludzko-zwierzęcych, jak też implementacji technologicznych stosowanych przez bohaterów (na przykład w literaturze science fiction) - w tym także przejmowania przez technologię właściwości zarezerwowanych dla człowieka.

Jest też poziom piąty. Dotyczy on bytów, które znamy tylko z nazwy, ale nie wiemy, jaka jest ich natura i, co więcej, nie dysponujemy żadnymi instrukcjami umożliwiającymi wyobrażenie sobie ich kształtu, funkcji czy ról (nie

${ }^{7}$ Dzieje się tak nie tylko w literaturze fantastycznej, baśniowej, ale także romantycznej. Wszystkie te nieludzkie podmioty sa projekcjami indywidualnych wyobraźni, które równie dobrze mogą istnieć w obiegu oralnym. Por. W.J. Ong, Oralność i piśmiennictwo. Stowo poddane technologii, tłum. i wstęp J. Japola, Lublin 1992, s. 186-188.

${ }^{8}$ Rozszerzenie takie ma szczególnie doniosłe znaczenie w obliczu pytań o charakter cyfrowej egzystencji podmiotu, w szczególności o to, gdzie podmiot jest i jak jest oraz w jakich warunkach to ,jest” może ulegać transformacjom i transgresjom. Jak usytuowanie podmiotu wpływa na jego akty poznawcze oraz na akty poznawcze tych wszystkich, którzy uczestniczą w projekcie. Co więcej, związki z technologią prowokują do jeszcze dalej idących pytań: czy częścią Ja pozostają udoskonalające jego somatyczność i sensoryczność implanty? Czy trans- i posthumanistyczne dyskursy podejmowane na gruncie sztuk performatywnych nie zapowiadają zmierzchu antropocenu? 
mówiąc już o esencji). Sytuację taką opisali niegdyś Ivor Amstrong Richards i Charles Ogden w The Meaning of Meaning (pierwsze londyńskie wydanie pochodzi z $1953 \mathrm{roku}$ ). Polega ona na tym, że dysponujemy nazwa, czyli punktem odniesienia albo referencem, ale nie dysponujemy referentem, czyli przedmiotem odniesienia (ani żadnym wyobrażeniem dotyczaçcym tego, jak mógłby on wyglądać $)^{9}$. Przykłady takich konstrukcji znajdujemy najczęściej w literaturze baśniowej, literaturze dla dzieci, fantastycznej, a także w mitach ${ }^{10}$. Lista ta może być tak długa, jak nieograniczona jest wyobraźnia ich twórców.

\section{3.}

Drugie uściślenie stosowane przez literaturoznawców odnosi się do gatunków. Oznacza to, że o postaciach literackich (także tych nieludzkich) myślimy w sposób zgodny z ich genologicznym pochodzeniem. Wynika to z tego, że postacie są niejako zakładnikami gatunków, w których występuja. Postać nie może stworzyć kontrfabularnego ciagu zdarzeń wobec tego, w który została wpisana, i nie potrafi o sobie pomyśleć w inny sposób niż w ten, w którym utrwalił ją autor. Nie może się też zbuntować czy uciec. Nawet jeśli takie projekty poruszają wyobraźnię czytelników i badaczy, to każda ucieczka postaci z przestrzeni dzieła (fabuły, stylu, języka czy formy) jest częścią zaplanowanej przez autora strategii. Postaci mogą poszukiwać autora, ale to od niego zależy przebieg takiego poszukiwania i jego ostateczny efekt.

$\mathrm{Z}$ tych właśnie powodów ważnym elementem gatunkowego bytu postaci jest ich związek z fabułą i akcją ${ }^{11}$. Pisał o tym już Arystoteles w odniesieniu

${ }^{9}$ Zob. J. Ziomek, Retoryka opisowa. Wrocław 1990, s. 138.

${ }^{10}$ Jeśli powiemy, że drogą idą gwajzle w towarzystwie murpli i cipagów, to posłużymy się wyłącznie nazwami, które nie mają referentów, czyli przedmiotów odniesienia. Co więcej, rozpoznając reguły wytwarzające owe byty, będziemy mogli z łatwością ów egzotyczny korowód wydłużyć o: haraczki, ośmioły, kwajsztance, dezdymury i liwoborki, gwajzdrule, ciuoruki, pucmoki i wojlitury. Warto jednocześnie dodać, że wyobrażenie sobie (konkretyzacja) bytu $a b$ nihilo jest szczególną formą konkretyzacji. Dzieje się tak dlatego, że utrwalone w literaturze byty nieludzkie, takie jak: smoki, czarownice albo wilkołaki, konkretyzowane są na podstawie utrwalonych społecznie i kulturowo schematów. W przypadku haraczków, gwajzli czy murpli nie mamy do czynienia z żadnymi schematami. Przeciwnie, ich konkretyzacja polega na tworzeniu wyobrażeń bez odniesienia do rozpoznawalnych wzorców.

${ }^{11}$ Zarówno chaotyczne czyny postaci, jak też tworzące ciagi przyczynowo-skutkowe pozwalają na osadzenie ich (postaci) w fabułach. To one właśnie sa zazwyczaj przedmiotem literackich narracji. Nie oznacza to, że postaci zawsze poznajemy w działaniu, ale że działanie pozostaje dla nich kluczową charakterystyką. Właściwość tę ujawniają także utwory eksponujące wewnętrzne doświadczenia podmiotu - nawet dzieło Marcela Prousta odnosi się do działań postaci i ich czynów. Dotyczy to także postaci, które nic nie robią i nie uczestniczą w żadnych fabułach (tak jak bohaterowie czekający na swojego Godota z dramatu Samuela Becketta). 
do eposu i tragedii. Przekonanie Stagiryty, że tragedia nie może obyć się bez akcji, ale może obyć się bez charakterów, podczas gdy epopeja przeciwnie, nie może się obyć bez charakterów, ale może się obyć bez akcji - zaprojektowało na wiele stuleci sposób myślenia o związkach postaci z fabułą (i szerzej gatunkami) ${ }^{12}$.

Szczególnie wiele dla ich rozpoznania uczynił - w latach trzydziestych XX wieku - Dawid Hopensztand. Analizując Czarne skrzydta Kadena-Bandrowskiego, dostrzegł związek między konstrukcją postaci i fabuła. Zależność tę opisał za pomocą chwytu nf: nihil est in fabula quot non fuerit prius in capitole dramatis personae (nie ma niczego w fabule, czego nie byłoby pierwej w głównej postaci dramatu). Oznacza to, że patrząc na postać, możemy przewidzieć, co się jej przytrafi. I co więcej, to, co się postaci przytrafi, będzie zależało od formy, w której jej losy zostały przedstawione (co innego przytrafi się w komedii, tragedii, w powieści realistycznej czy groteskowej) ${ }^{13}$.

Chwyt opisany przez Hopensztanda ujawnia swoją historycznoliteracką ciagłość. W czasach greckich reguł odnoszących się do postaci i gatunków strzegła zasada stosowności - decorum - mówiąca o tym, że w tragediach występuja postaci wysokie, podczas gdy w komediach i dramatach satyrowych - niskie. Warto też przypomnieć - szczególnie w czasach zanikającej znajomości starej greki - że na straży zasad antycznej stosowności stało metrum. Dla widzów antycznego teatru było więc najzupełniej zrozumiałe, że postaci tragedii nie mówią kulawym jambem - właściwym dla komedii, a chór tragiczny wchodził na orchestrę w rytmie podniosłego metrum - na przykład peonu trzeciego.

Zasadę stosowności - dopasowania postaci do gatunku i językowego stylu - w czasach późniejszych podtrzymywała literatura bohaterska, opiewająca heroiczne czyny postaci i unieśmiertelniająca ethos rycerski. Najbardziej znanymi jej świadectwami - obok Iliady, Odysei i Eneidy - pozostaja: znienawidzona przez licealistów Pieśn o Rolandzie czy znane już tylko literaturoznawcom Jerozolima wyzwolona (Gerusalemme liberata - 1575) Torquato Tassa oraz Orland szalony (Orlando furioso - 1516) Lodovica Ariosta.

Dodać trzeba jednocześnie, że - obok kryteriów gatunkowych - na byt postaci literackich wpływa również tradycja interpretacyjna. Dobrym przykładem może być Odys. Oprócz heroicznego wizerunku zwycięzcy spod Troi, spopularyzowanego przez Homera i Cycerona, a następnie często przywoływanego przez twórców nowożytnych, utrwalił się też inny jego obraz. Odys demagog, cynik i okrutnik został przedstawiony w Filoktecie (409 p.n.e.)

${ }^{12}$ Arystoteles, Poetyka 1450a,25, tłum. H. Podbielski, BN seria II, nr 209, Wrocław 1983, s. 19.

${ }^{13}$ Zob. D. Hopensztand, Mowa pozornie zależna w kontekście „Czarnych skrzydet”, [w:] Stylistyka teoretyczna w Polsce, red. K. Budzyk, Warszawa 1946, s. 299-330. 
Sofoklesa oraz trzech sztukach Eurypidesa: Hekabe (424 p.n.e.), Trojankach (415 p.n.e.) i Cyklopie (413 p.n.e.). W Filoktecie porzuca on na Lemnos rannego towarzysza broni. W Trojankach dokonuje mordu na dziecku - synu Hektora o imieniu Astykanaks. W Hekabe nie znajduje litości dla żony Priama - staruszki, która uratowała mu życie, gdy w przebraniu żebraczym został schwytany pod murami Troi. Taką interpretację utrwalili najpierw Pindar i Platon, a następnie Owidiusz w Metamorfozach i Seneka w Trojankach. Do tej tradycji nawiązał też Szekspir w Troilusie i Kressydzie (1602), a także Racine w Ifigenii w Aulidzie (1674), Hauptmann w Łuku Odyseusza (1914), Wyspiański w Powrocie Odysa (1907), Giraudoux w Wojny trojańskiej nie będzie (1935), wreszcie James Joyce w Ulissesie za sprawą postaci Leopolda Blooma (1922) ${ }^{14}$.

Pomyśleć o Odysie - oznacza więc pomyśleć o gatunku i wpisanej weń tradycji interpretacyjnej (także językowej). Odys w różnych maskach (tragicznej, komicznej, tragikomicznej, farsowej czy burleskowej) tworzy niejako wiązkę bytów równoległych. Paralelność jego egzystencji - która jest jednocześnie typowa dla wielu innych postaci literackich - uświadamia, że genologia, tradycja interpretacyjna i styl nie tylko unieśmiertelniają literackie postaci, ale także pozwalają na ich istnienie wariantywne.

\section{4.}

Trzecie uściślenie stosowane przez literaturoznawców odnosi się do egzystencji dzieła literackiego i tego, jak jawi się ono odbiorcy. Szczególnie wiele w tym względzie zawdzięczają literaturoznawcy Romanowi Ingardenowi. Przypomnieć jednak trzeba, że rozważania Ingardena na temat istnienia dzieła literackiego - czyli tego: ,jak ono jest” - stanowiły część znacznie szerzej zakrojonych dociekań, odnoszących się do sposobu istnienia świata, zawartych w dziele życia Ingardena, to znaczy w Sporze o istnienie świata. Kluczową kwestia pozostawało dla autora pytanie „jak istnieje świat?”. O tym, że istnieje on w sposób niepodważalny, decydować miała - zdaniem Ingardena - jego niezależność od aktów świadomości podmiotu. Ze względu na to, że liczne procesy należące do świata zachodzą bez woli podmiotu, wyprowadzić można wniosek, że muszą one istnieć realnie, a zatem - że realnie istnieje również świat.

${ }^{14}$ Podwójna biografia Odysa brała swój początek w historii jego przodków. Z jednej strony był on synem szlachetnego Laertesa, reprezentującego pokolenie wodzów i ethos rycerski, z drugiej był wnukiem Autolikosa, znanego z forteli i przechowującego w swej biografii element niski, plebejski. Zob. J. Abramowska, Odys wspótczesny, [w:] Topika antyczna w literaturze polskiej XX wieku, red. A. Brodzka, E. Sarnowska-Temeriusz, Wrocław 1992, s. 42. 
Efektem namysłu Ingardena stało się pytanie: czy istnieją byty, które mają wyłącznie intencjonalną naturę, to znaczy takie, które są wytworem świadomości podmiotu i poza nią (świadomościa) nie istnieją? Dociekania te, jak wiadomo, doprowadziły autora do rozważań na temat dzieła sztuki, a w szczególności do dzieła literackiego, które nieprzypadkowo stało się ulubionym przedmiotem jego badań. Szczególnie ważną refleksję na temat unikalności dzieła literackiego przedstawił on w związku z analizą drugiej teorii Husserla (w której pojawiły się propozycje dotyczące noezy i noematu) ${ }^{15}$. Ingarden usiłował rozwiązać zawarte w niej niejasności, a w szczególności scharakteryzować rolę samego noematu, który może być celem intencji, ale również zapośredniczeniem intencji, wreszcie - wytworem świadomego aktu ${ }^{16}$. Prawdziwie ważnym zwrotem stało się stwierdzenie Ingardena, że noemat (który określił mianem przedmiotu czysto intencjonalnego) jest zależny od samej (immanentnej) treści intencji - to znaczy noezy. Oznaczało to, że przedmioty intencjonalne (noematy) nie mogą być przedmiotami w znaczeniu, które opisał Alexius Meinong ${ }^{17}$ (a więc takimi, które są - to znaczy istnieją - niezależnie od skierowanej na nie intencji), lecz przeciwnie, stanowią wyłączne wytwory aktów świadomości (noez) i całkowicie się w nich zawierają. Wypływa stąd wniosek, że przedmiot intencjonalny (noemat), chociaż zostaje wytworzony przez akt intencjonalny, to raczej nie stanowi przedmiotu tego aktu ${ }^{18}$.

Oznacza to, że jeśli chcę pomyśleć o przedmiocie $\mathrm{P}$ za pomocą znaczenia Z, to wytwór mojego namysłu pozostaje w ścisłym związku z zawartością przedmiotu, ale zawartość nie musi pozostawać w związku z przedmiotem. Innymi słowy, mamy tu do czynienia z relacją niezwrotną lub jednokierunkową. Jeśli myślę o Odysie, to - niezależnie od tradycji interpretacyjnej, do której się odnosze - wytwarzam przedmiot intencjonalny w oparciu o dostępną zawartość (znaczenie). W ten sposób ów przedmiot - jak mówi Ingarden - „staje mi przed oczami”. Niezwrotność tej relacji polega jednak na tym, że sam akt

${ }^{15}$ Zob. E. Husserl, Vorlesungen über Bedeutungslehre. Sommersemester 1908, (Husserliana XXVI, hrsg. von U. Panzer), Dordrecht 1986, s. 35.

${ }^{16}$ Zob. A. Chrudzimski, Teoria intencjonalności Romana Ingardena, „Edukacja Filozoficzna" 1998, 25, s. 249-250.

${ }^{17}$ A. Meinong, „Über Gegenstandstheorie”, in Gesamtausgabe, Bd. II, Graz 1971, s. 481535.

${ }^{18}$ Aby rzecz lepiej zrozumieć, przywołać trzeba uwagi Ingardena na temat dwóch szeregów własności przysługujących przedmiotowi intencjonalnemu. Pierwszy dotyczy samego przedmiotu intencjonalnego, a więc tego, że jest on wytworzony przez poznajacy podmiot, że stanowi efekt jego wysiłku poznawczego i jako taki stanowi (do pewnego stopnia) jego poznawczą wartość. Drugi dotyczy jego zawartości, a więc tego, co stanowi poznawczą treść przedmiotu. Tutaj konieczne jest odróżnienie samego przedmiotu intencjonalnego jako takiego od jego zawartości, która jest określona przez treść naoczną aktu mniemania (dzięki czemu ów przedmiot może zostać ustanowiony w akcie intencjonalnym). 
intencjonalny ma ograniczony wpływ na tę zawartość. Moje myślenie nie zmienia zatem znaczenia przedmiotu. Nie czyni zawartości inna, niż ona jest.

Szczególnie ważne dla literaturoznawców okazało się jednak to, że Ingarden ulokował noematy i noezy w czterowarstwowej i dwuwymiarowej strukturze dzieła literackiego. Oznacza to, że o przedmiotach czysto intencjonalnych można pomyśleć poprzez brzmienia i sensy, do których brzmienia się odnoszą (obiekty i postaci, o których literatura opowiada), a dalej poprzez cały świat przedstawiony, w którym owe obiekty i postaci występują oraz poprzez wyobrażenia, które jako odbiorcy mamy na ich temat lub/i które możemy sobie wyobrazić. W ten sposób intencjonalny byt dzieła literackiego może być wytwarzany/wywoływany zarówno przez połaczenie owych poziomów, jak też przez każdy z nich z osobna. Przy tej okazji pojawiają się jednak pewne komplikacje.

Jeśli z łatwością mogę pomyśleć o postaciach z powieści Tomasza Manna (o Madame Chauchat, Settembrinim i Naphcie), to muszę jednocześnie zapytać: czy istnieje jakaś uniwersalna - językowa - forma ich prezentacji? Czy istnieje znormalizowana warstwa brzmieniowa Czarodziejskiej góry (jednolita: prozodia, artykulacja, tempo)? Jak ma się w tym zakresie do niemieckiego oryginału przekład polski (także przekład drugiego tomu dokonany - o czym nie wszyscy filozofowie wiedzą - przez Władysława Tatarkiewicza, występującego pod pseudonimem Jan Łukowski)? Czy przedmioty przedstawione w powieści mają takie samo znaczenie dla wszystkich czytelników (a więc czy są tak samo przez nich dekodowane - rozumiane)? Wreszcie czy czytelnicy wyobrażają sobie tak samo schematyczne wyglądy przedmiotów? A więc, czy czytając, że „krzesło stało przy stole”, wyobrażaja sobie takie same meble? Czy zatem różnice na poziomie konkretyzacji przedmiotów nie wpływają na poziom znaczeń?

Pytania te - na które dość łatwo można odpowiedzieć - prowadzą do dwóch konkluzji. Pierwsza, że dzieło literackie może być przedmiotem licznych konkretyzacji oraz, że one same przebiegaja - jak pisał Ingarden dwutorowo; sa wykładnikiem relacji między dziełem a atmosferą literacką epoki oraz w drugim rzędzie stosunku czytelnika do dzieła ${ }^{19}$. Świadczą o tym w szczególności konkretyzacje dzieł, z którymi mamy do czynienia w teatrze i filmie. Dzięki temu powstają nowe warianty znanych fabuł (zdarza się, że są silniej rozpoznawalne niż pierwowzory) ${ }^{20}$.

Druga konkluzja dotyczy skutków Ingardenowskiego ujęcia, o których pewna część czytelników nie pamięta albo nie wie. Chodzi mianowicie o to, że sądy przedstawiane w dziełach literackich stoją poza asercją, co znaczy, że

${ }^{19}$ Zob. R. Ingarden, Studia z estetyki, t. 1, Warszawa 1956, s. 242 oraz tegoż, O dziele literackim, Warszawa 1960, s. 431-432.

${ }^{20}$ Por. S. Wysłouch, Literatura i semiotyka, Warszawa 2001, s. 75-115. 
nie stosują się do nich proste kategorie prawdy i fałszu, z którymi mamy do czynienia w innych obszarach komunikacji językowej. Świat przedstawiony $\mathrm{w}$ dziele literackim, nawet jeśli pozostaje w rozpoznawalnych relacjach do rzeczywistości fizykalnej, nie jest z nią równoznaczny. Słowa wypowiadane w dziele literackim nie maja realnych skutków. Rozpoczać powieść od deklaracji, że się zabije wszystkich czytelników, nie oznacza, że się to zrobi naprawdę, ale tylko, że się to zrobi (jeśli się to zrobi) w granicach świata przedstawionego, to znaczy w granicach konwencji właściwej dla dzieła artystycznego.

Nieświadomość owej umowy prowadzi do tak zwanego naiwnego (albo nieprofesjonalnego) odbioru - i odnosi się nie tylko do literatury, ale także do innych sztuk, w szczególności do filmu i teatru. Świadczą o czym liczne anegdoty mówiące o nieobeznanych z konwencjami estetycznymi widzach, którzy dopominają się, aby aktorzy grający role lekarzy przyjmowali ich krewnych do szpitali. Brak znajomości konwencji literackiej stał się też źródłem kilku artystycznych skandali, których bohaterami byli między innymi Gustaw Flaubert po napisaniu Pani Bovary czy Vladimir Nabokov po opublikowaniu Lolity (z braku kompetencji odbiorczych wypływają także skandale teatralne: Golgota Picnic Rodriga Garcii - po interwencji środowisk prawicowych i kościelnych - została zdjęta z programu Festiwalu Malta w 2014 roku; podobne protesty wywołała Klatwa Stanisława Wyspiańskiego w reżyserii Olivera Frljicia z Teatru Powszechnego w Warszawie).

Szczególnie ważna dla refleksji na temat odbioru dzieła literackiego wydaje się polemika, którą z Romanem Ingardenem podjął Stanisław Lem. W obszernych fragmentach Filozofii przypadku odrzucił on zasadę geologicznej lub stereometrycznej budowy dzieła literackiego (uznając, że nie jest ona własnością genotypu, lecz sekwencji „wyłączeń”, „kroków lektury”. Innymi słowy, to „nie dzieło jest warstwowym utworem hierarchicznym, ale proces jego odbioru tak się przedstawia" ${ }^{21}$. Lem podważył też konieczność konkretyzacji uschematyzowanych wyglądów. Według niego nie muszą one przybierać zawsze takiej samej postaci i, co więcej, moga jej w ogóle nie przybierać. Zdolni jesteśmy wyobrazić sobie czytelnika pozostającego - jak mówi Lem - na poziomie satysfakcji brzmieniowo-znaczeniowej. Takiego zatem, który dla uzyskania pełnej satysfakcji poznawczej (w jego własnym rozumieniu tej satysfakcji) nie musi sobie niczego konkretyzować.

Dzieło Lema otworzyło jednocześnie drogę do szerszej refleksji na temat sposobu, w jaki dzieło literackie jawi się czytelnikowi. Nie chodzi tu jednak wyłącznie o jego budowę, strukturę, zaplanowany i zrealizowany porządek, ale raczej o to, za pomocą czego dzieło dla odbiorcy „jest”. W jaki sposób

${ }^{21}$ S. Lem. Filozofia przypadku. Literatura w świetle empirii, Kraków 1968, s. 327. 
„staje się" i w jaki sposób się konkretyzuje, a także przekształca i od czego te zmiany zależą? Wreszcie, czy w procesie jego odbioru mamy do czynienia $\mathrm{z}$ wypracowanymi regułami, matrycami rozumienia, czy przeciwnie (z brakiem reguł)?

\section{5.}

Pogląd, że dzieło literackie czy, szerzej, dzieło sztuki, powstaje w planie odbiorczym, nie był też obcy Ingardenowi, który mówił o tym, że noeza pozostaje emanacją immanencji podmiotu ${ }^{22}$. W ten sposób dzieło staje się przedmiotem komunikacyjnej gry między autorem i jego odbiorcami, przebiegającej w granicach wyznaczonych przez graczy. Dzieło staje się dzięki temu przedmiotem negocjacji, reinterpretacji i rekontekstualizacji wpisanych z jednej strony w proces historycznoliteracki, z drugiej w indywidualne warunki odbioru, wypływające z immanencji odbiorcy.

Ujęcie takie ma dodatkowa zaletę: pozwala na obronę fenomenologii przed zarzutami aprioryczności. Umożliwia bowiem sformułowanie opinii, że intencjonalność dzieła sztuki nie jest czymś danym, ale powstaje w akcie jego odbioru (a więc, że nie ma w rzeczywistości wymiaru apriorycznego) ${ }^{23}$. Składa się z dekodowania określonych treści w ustalonym porządku, ale także z tworzenia przedmiotów czysto intencjonalnych po stronie odbiorcy, które wymagają dodatkowo pewnej jego aktywności. Aktywność odbiorcy pozwala odejść od koncepcji Husserlowskiego biernego umysłu i skłania się ku aktom czynnym, o których pisał wcześniej Franz Brentano ${ }^{24}$.

${ }^{22}$ Zamierzeniem wybitnego uczonego było opisanie dzieła literackiego z perspektywy metafizycznego realizmu, to znaczy w sposób sprzeciwiający się transcendentalnemu idealizmowi, który wypracował jego wielki mistrz Edmund Husserl.

${ }^{23}$ Podejściu fenomenologicznemu zarzucano między innymi, że w próbie uchwycenia istoty przedmiotów i zjawisk zakłada się apriorycznie, że taką istotę posiadają to znaczy, że u podstaw przedmiotów znajduje się jakaś esencja, za sprawą której uzyskują one swoją tożsamość. Wiemy jednak, że pewna część przedmiotów nie posiada esencji albo, że jest ona niemożliwa w ich przypadku do uchwycenia, natomiast ujawniają się one (przedmioty) poprzez pełnione funkcje. Jakkolwiek charakterystyka przedmiotów za pomocą funkcji pozostaje w konflikcie z poznaniem fenomenologicznym, to jednak, z drugiej strony, potrafimy powiedzieć, że zarówno funkcje, jak też esencje mogą stanowić przedmiot aktu intencjonalnego (noezy). Kluczowe dla analizy dzieł artystycznych wydaje się zatem nie to, czy noematy posiadają konieczną esencjonalność, ale czy potrafimy właściwe ukierunkować noezę w taki sposób, żeby umożliwiała wytworzenie noematu (przedmiotu intencjonalnego).

${ }^{24}$ F. Brentano, Psychologia z empirycznego punktu widzenia, tłum. W. Galewicz, Warszawa 1999 (Psychologie vom empirischen Standpunkt, wyd. 1, 1874, wyd. 2, red. O. Kraus, Leipzig 1924-1925). Refleksja Franza Brentana na temat intencjonalności miała swoje silne umocowanie w XIX-wiecznej fascynacji naukowością i wyrastała z przekonania, że do opisu 
Jeśli uczynimy takie założenia, to stanie się zrozumiałe, że dzieło literackie (a może szerzej: artystyczne) jawić się będzie jako zbiór aktów komunikacyjnych, które przebiegają wedle określonych reguł, przyzwyczajeń i tradycji. Tak długo, jak długo gracze - uczestnicy procesu artystycznego (komunikacyjnego) - skłonni są przestrzegać wspólnych reguł gry (reguł wyznaczonych przez właściwości dzieł i epok), tak długo mamy do czynienia z gra.

Kluczowe wydaje się w tym kontekście pytanie: jak owa gra przebiega? Na jakich regułach się opiera? W jaki sposób tworzy się obraz dzieła u uczestnika procesu historycznoliterackiego? Czy dawne dzieła literackie istniały inaczej dla swoich odbiorców niż dla współczesnych? Czy sposób odbioru dzieła literackiego wynika z jego właściwości, czy z predyspozycji poznawczych czytelnika? A może z tego, co nazywamy tradycją estetyczną i wykształceniem literackim?

Odpowiedź na te pytania kryje się w sposobie myślenia odbiorcy o dziele literackim. Wydaje się, że mamy tu do czynienia z zaskakująco niezmiennymi regułami. Myślenie czytelnika ma bowiem postać synekdochiczno-performatywna. Z jednej strony opiera się na wyborze elementów (noematów), które staja się przedmiotami interpretacji. Przybiera więc postać synekdochy (pars pro toto), która jest częścią zamiast całości. Wynika to z tego, że o dziele literackim myślimy zawsze poprzez jakaśs jego część, poprzez fragment, który reprezentuje całość. Najczęściej dotyczy on pojedynczego obrazu, ale może się też odnosić do formy, kompozycji czy języka. Przypomnienie sobie części wymaga jednocześnie wpisania jej w fabułę i akcję. $\mathrm{O}$ wybranej scenie nie myślimy w oderwaniu od tego, co ją poprzedziło i co

życia - zarówno w jego wymiarze indywidualnym, jak też zbiorowym - niezbędne są nowe metodologiczne narzędzia, wykraczające poza poznawcze możliwości dotychczasowej psychologii (rozumianej jako Arystotelesowska). Z Arystotelesowskiej „nauki o duszy” pragnął Brentano uczynić dyscyplinę zajmującą się fenomenami (zjawiskami) psychicznymi (por. D. Münch, Intention und Zeichen. Untersuchungen zu Franz Brentano und zu Edmund Husserls Frühwerk, Frankfurt am Main 1993, oraz: K. Sachs-Hombach, Philosophische Psychologie im 19. Jahrhundert. Ihre Ent - stehung und Problemgeschichte, Freiburg-München1993). Projekt Brentany opierał się na oddzieleniu metafizycznych rozważań na temat duszy (jako trwałej substancji wpisanej w byt, która doznaje aktów - przypadłości - psychicznych) od empirycznego przedmiotu doświadczeń psychicznych (doznań), które nie wymagają rozstrzygnięć na poziomie metafizycznym, ponieważ podlegają opisowi w wymiarze samego doświadczenia i w ten sposób wyrażają przekonanie nowoczesnej nauki mówiące o tym, że doświadczenie jest głównym i jedynym źródłem wiedzy. Błędem byłoby jednak twierdzenie, że dzieło Franza Brentana należy do tzw. psychologii empirycznej. W istocie refleksja niemieckiego uczonego na co zwrócił uwagę Roman Ingarden - wyraża głębokie fascynacje metafizyczne i epistemologiczne. Zob. R. Ingarden, Z badań nad filozofia wspótczesna, Warszawa 1963, s. 209-249. Por. także: A. Chrudzimski, Intentionalität, Zeitbewusstsein und Intersubjektivität. Studien zur Phänomenologie von Brentano bis Ingarden, Frankfurt 2005, s. 7-8. 
po niej nastapi. Przeciwnie, nawet jeśli skłonni jesteśmy kontemplować zatrzymany w myślach kadr, to mamy świadomość jego przynależności do większych struktur fabularnych. One właśnie wymuszaja podejście performatywne. Performatywność można tu rozumieć w dwojaki sposób: jako akt działania i „stwarzania rzeczywistości” (oczywiście wyłącznie w ramach świata przedstawionego w tekście). W ten sposób działające postaci staja się przedmiotem myśli czytelnika. $\mathrm{Z}$ drugiej strony działania postaci prowadzą do powstania efektów lub też quasi-efektów ${ }^{25}$, które mają wymierny wpływ na bieg zdarzeń.

Posłużę się prostym przykładem: jeśli chcę pomyśleć o Mistrzu i Matgorzacie Michaiła Bułhakowa, to nie myślę o całej powieści, tylko o jakimś jej fragmencie, scenie lub postaciach. Mogę więc pomyśleć o powieści (na przykład) poprzez scenę rozgrywającą się na Patriarszych Prudach, gdzie spotykają się Michaił Aleksandrowicz Berlioz i Iwan Nikołajewicz Ponyrow, publikujący pod pseudonimem Bezdomnyj, którzy przekonują Wolanda, że Jezus nigdy nie istniał. Dodać przy tym trzeba, że dla egzystencji postaci literackich Patriarsze Prudy i ich dawny, jak też współczesny wygląd nie mają większego znaczenia. Nie ma zatem znaczenia, że przez słynny skwer nie przebiegają i nigdy nie przebiegały tramwajowe tory, które stanowia jak wiadomo - kluczowy element sceny, w której komsomołka Annuszka (za pomoca oleju słonecznikowego) odcina głowę Berliozowi.

Przywołanie sceny z powieści Bułhakowa oznacza, że muszę wytworzyć noemat i noezę. Muszę wybrać scenę w poczuciu, że jest ważna i reprezentatywna dla mojego rozumienia dzieła. Muszę sobie ją nie tylko przypomnieć - a więc wytworzyć noemat - ale też nadać jej znaczenie - noezę, wynikająca z cech mojej immanencji. Dla obu tych czynności przydatne jest zobaczenie sceny w powiązaniu z wydarzeniami, które ją poprzedziły i które po niej nastapia - zobaczenie postaci w ruchu, w działaniu, a więc wyobrażenie sobie całej sekwencji zdarzeń, z których składało się spotkanie na Patriarszych Prudach.

Dodać trzeba, że przywoływane (przypominane) w ten sposób obrazy mogą być niezgodne z porządkiem kompozycyjnym dzieła (i tworzyć nową jego syntagmę). O powieści Bułhakowa mogę pomyśleć w sposób Cortazarowski, „skacząc” między scenami. W ten sposób mogę wytwarzać nowe

${ }^{25}$ Określenie „performatywne” w znaczeniu „sprawcze” w odniesieniu do dzieła literackiego jest zrozumiałym nadużyciem szczególnie wtedy, gdy skonfrontujemy ją z rozumieniem przedstawionym przez Johna Langshawa Austina (zob. Jak działać za pomocq stów, [w:] tegoż, Mówienie i poznawanie, tłum. J. Woleński, Warszawa 1993, s. 550-708). Mówiąc przeto o „sprawczym działaniu postaci”, można mieć na myśli wyłącznie taką sprawczość, która mieści się w rzeczywistość dzieła literackiego, które opiera się na quasi-sądach i stoi poza skala prawdy i fałszu. 
sensy, ponieważ zmiany o charakterze składniowym (to znaczy zmiany dotyczące kolejności przypominanych sobie zdarzeń) maja - jak wiemy - konsekwencje semantyczne. Jeśli zatem wyobrazimy sobie grupę czytelników, którzy po lekturze powieści Bułhakowa zechcą o niej pomyśleć w sposób dla siebie dogodny, to stanie się zrozumiałe, że ich synekdochiczno-performatywne rozumienia moga zmieniać porządek fabularny i konstrukcyjny samego dzieła, a na dodatek znaczaco się od siebie różnić (i prowadzić do powstawania usprzeczniających się sensów). Dzieje się tak dlatego, że powstają one na podstawie odmiennych i spersonalizowanych noez. Tłumaczy to - w jakimś stopniu - fenomen różnic interpretacyjnych, które powstaja na gruncie tego samego doświadczenia estetycznego ${ }^{26}$.

\section{6.}

Scharakteryzowane tu właściwości dotyczące odbioru dzieła literackiego prowokują do postawienia pytania o ich przydatność do badania dzieł nie tylko literackich. Do tego: czy inne dzieła wyobrażamy sobie w podobny sposób jak literackie? W szczególności: czy na bazie synekdochiczno-performatywnej kliszy powstają noematy i noezy dzieł należących do sztuk wykonawczych (performatywnych) teatru, filmu, a także sztuk plastycznych i muzycznych?

Szczególna trudność pojawia w wypadku analizy dzieła teatralnego, sytuacja postaci teatralnej jest bowiem bardziej złożona niż literackiej. Aby się o tym przekonać, należy zapytać: gdzie jest postać teatralna po zakończeniu przedstawienia? Gdzie jest po latach, gdy przedstawienia już nie ma? Jeśli nie mogę sprawdzić, jak istniała (bo nie dysponuję żadnymi zapisami ani świadectwami materialnymi), to skąd wiem, czy w ogólne istniała? Może ujawnia się wyłącznie wspominającemu ją podmiotowi, podobnie jak duch ojca Hamleta, o którym nie wiemy ,jak jest”, ponieważ nie ujawnia się wszystkim? Jeśli jednak mogę o postaci pomyśleć, to czy rzeczywiście jej nie ma?

$\mathrm{Z}$ drugiej jednak strony nie wydaje się - mówiąc językiem Ingardena żeby forma dzieła decydowała o samej noezie. Z punktu widzenia odbiorców pierwotny kształt przedmiotów występujących w dziełach artystycznych ma tylko takie znacznie, jakie łączy się z ograniczeniem lub ukierunkowaniem powstawania noematów i noez na poziomie indywidualnych wyobrażeń ${ }^{27}$.

${ }^{26}$ Zob. G. Deleuze, Różnica i powtórzenie, tłum. B. Banasiak, K. Matuszewski, Warszawa 1997 , s. $81-116$.

${ }^{27}$ Osobnym zagadnieniem, które wymagałoby bardziej szczegółowych rozstrzygnięć, jest: na ile tworzone noematy wpisują się w procesy psychologiczne, o których wspominał Franz Brentano (por. R. Ingarden, O pytaniach esencjalnych, [w:] tegoż, Z teorii języka i filozoficz- 
W tym kontekście znacznie ważniejszy, a może decydujący, okazuje się mechanizm stwarzający noematy i noezy. To on w końcu przesądza o tym, jak dzieło ujawnia się publiczności, a więc jak ono ,jest”. Mechanizm ten jest podobny w przypadku literatury, teatru, a także filmu. Jego synekdochiczno-performatywna natura pozwala na tworzenie takich rozumień odbiorczych, które uniezależniaja się od swoich artystycznych odniesień. Dzięki temu można rozmawiać o przedstawieniach teatralnych, które już dawno zostały zdjęte $\mathrm{z}$ afisza (i nie były zarejestrowane), jak też o książkach przeczytanych przed wieloma laty, których się dobrze nie pamięta. Nawet jeśli uczestnicy takich rozmów nie mają dostępu do dzieł artystycznych (noematów), to moga rozmawiać o swoich rozumieniach owych dzieł (noezach), utrwalonych za pomocą synekdochiczno-performatywnych klisz. W ten sposób mogą nie tylko powoływać dawne dzieła do życia, ale także wprowadzać je do obiegu, nadawać im sens społeczny i komunikacyjny.

\section{BIBLIOGRAFIA}

Annas J., An Introduction to Plato's Republic, Oxford 1981.

Arystoteles, Poetyka 1450a, 25, tłum. H. Podbielski, BN seria II, nr 209, Wrocław 1983. Austin J.A., Jak działać za pomoca słów, [w:] tegoż, Mówienie i poznawanie, tłum. J. Woleński, Warszawa 1993, s. 550-708.

Bartol K., Wypędzić poezję, wygnać poetów. Wspótczesne interpretacje Platońskiego postulatu, „Poznańskie Studia Polonistyczne” Seria Literacka, 2012, nr 19, s. 13-30.

Brentano F., Psychologia z empirycznego punktu widzenia, tłum. W. Galewicz, Warszawa 1999.

Chrudzimski A., Intentionalität, Zeitbewusstsein und Intersubjektivität. Studien zur Phänomenologie von Brentano bis Ingarden, Frankfurt 2005.

Chrudzimski Z., Teoria intencjonalności Romana Ingardena, „Edukacja Filozoficzna” 1998, 25, s. 249-250.

Deleuze G., Różnica i powtórzenie, tłum. B. Banasiak, K. Matuszewski, Warszawa 1997.

Gawroński A., Dlaczego Platon wykluczyt poetów z państwa? U źródet wspótczesnych badań nad językiem, przedmowa Z. Kubiak, Warszawa 1984.

Hopensztand D., Mowa pozornie zależna w kontekście „Czarnych skrzydet”, [w:] Stylistyka teoretyczna $w$ Polsce, red. K. Budzyk. Warszawa 1946.

Husserl E., Vorlesungen über Bedeutungslehre. Sommersemester 1908, "Husserliana" XXVI, hrsg. von U. Panzer, Dordrecht 1986.

Ingarden R., O dziele literackim, Warszawa 1960.

Ingarden R., O pytaniach esencjalnych, [w:] tegoż, Z teorii języka i filozoficznych podstaw logiki, Warszawa 1972.

Ingarden R., Studia z estetyki, t. 1, Warszawa 1956.

nych podstaw logiki, Warszawa, s. 343-357; oraz J. Krokos, Odstanianie intencjonalności, Warszawa 2013, s. 19.) 
Ingarden R., Z badań nad filozofia wspótczesna, Warszawa 1963.

Krokos J., Odstanianie intencjonalności, Warszawa 2013, s. 19.

Lem S., Filozofia przypadku. Literatura w świetle empirii, Kraków 1968.

Meinong A., „Über Gegenstandstheorie”, in Gesamtausgabe, Bd. II, Graz 1971, s. 481-535.

Münch D., Intention und Zeichen. Untersuchungen zu Franz Brentano und zu Edmund Husserls Frühwerk, Frankfurt am Main 1993.

Ong W.J., Oralność i piśmienność. Stowo poddane technologii, tłum i wstęp J. Japola, Lublin 1992.

Platon, Ion, 534 B-C, [w:] tegoż, Dialogi, t. 1, tłum. W. Witwicki, Kęty 1999.

Platon, Państwo, 597-598, [w:] tegoż, Państwo, Prawa, tłum. W. Witwicki, Kęty 1999.

Sachs-Hombach K., Philosophische Psychologie im 19. Jahrhundert. Ihre Ent-stehung und Problemgeschichte, Freiburg-München 1993.

Szczepańska A., Estetyka Romana Ingardena, Warszawa 1989.

Topika antyczna $w$ literaturze polskiej XX wieku, red. A. Brodzka, E. Sarnowska-Temeriusz, Wrocław 1992.

Wawrzyniak A., Egzystencja, [w:] Powszechna encyklopedia filozofii, red. A. Maryniarczyk, t. 3, Lublin 2002, s. 33-34.

Wysłouch S., Literatura i semiotyka, Warszawa 2001.

Ziomek J., Retoryka opisowa, Wrocław 1990. 